\title{
Retinal and intracranial hemorrhage in acute leukemic disseminated intravascular coagulation
}

Figure 1 Leukemic retinal and intracranial hemorrhage on CT
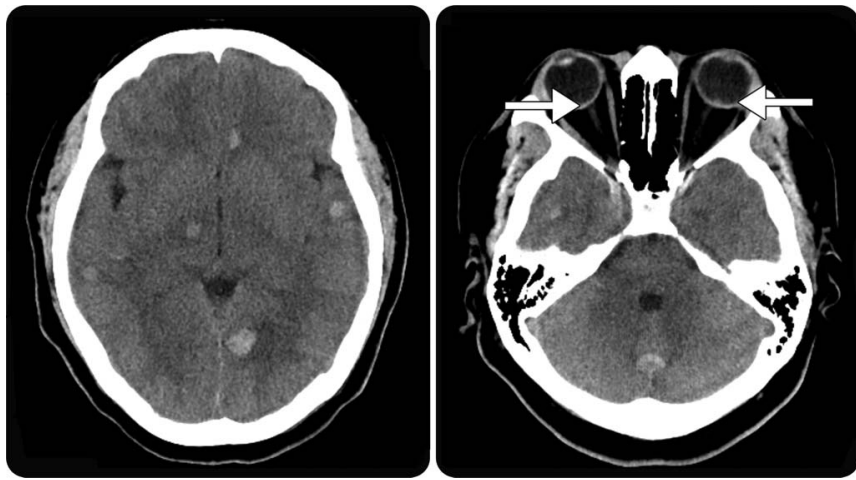

Axial CT images show multiple acute supratentorial and infratentorial intraparenchymal hematomas, as well as hemorrhage within the posterior globes bilaterally (arrows).

Figure 2 Leukemic retinal and intracranial hemorrhage on MRI
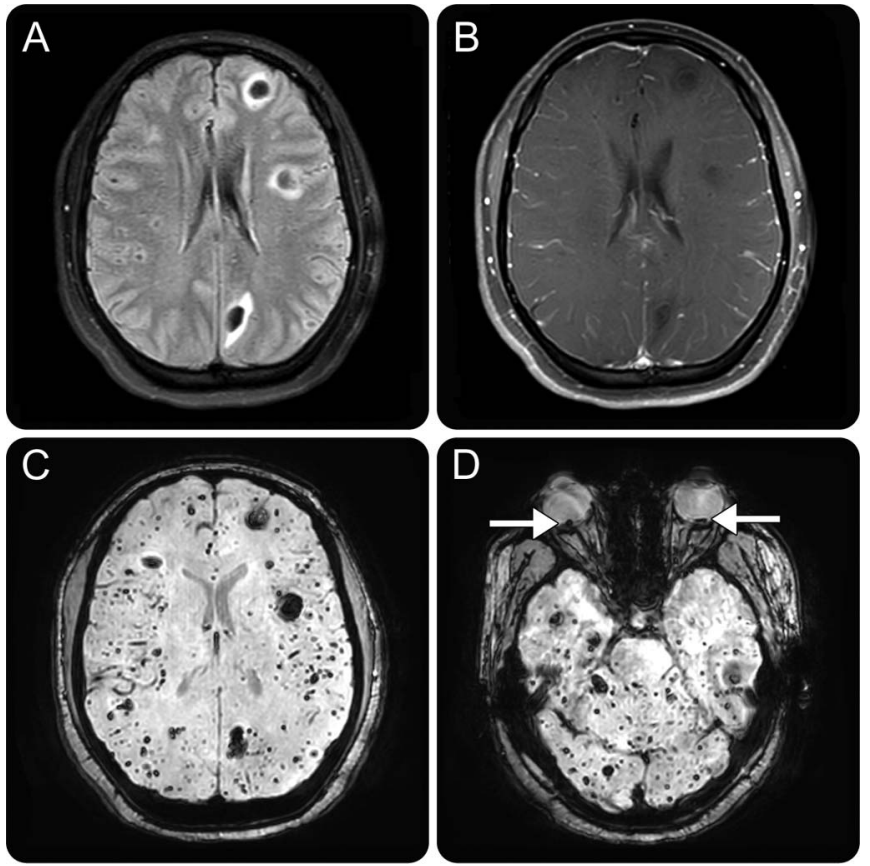

Axial T2 fluid-attenuated inversion recovery (A), postcontrast T1 (B), and susceptibility-weighted images (C, D) obtained shortly after the CT show numerous multifocal cortical and subcortical acute intraparenchymal hematomas with mild vasogenic edema, but no associated enhancement, as well as bilateral retinal hemorrhages (arrows).

A 22-year-old woman with an unremarkable medical history presented with recent fever, epistaxis, ecchymosis, altered mental status, and blurry vision. Leukocyte count was 147,000, platelet count was 23 , and blood smear was consistent with acute promyelocytic leukemia in the setting of disseminated intravascular coagulation. Ophthalmoscopy demonstrated retinal hemorrhages consistent with leukemic retinopathy. CT (figure 1) 
and MRI (figure 2) of the head demonstrated characteristic numerous multifocal cortical and subcortical hemorrhages in addition to the retinal hemorrhages, which were particularly striking on the susceptibilityweighted imaging. ${ }^{1}$ Retinopathy at presentation of adult leukemia portends a poor prognosis. ${ }^{2}$

Daniel Thomas Ginat, MD, MS, Gregory A. Christoforidis, $M D$

From the Department of Radiology, Pritzker School of Medicine, University of Chicago, Chicago, IL.

Study funding: No targeted funding reported.

Disclosure: The authors report no disclosures relevant to the manuscript. Go to Neurology.org for full disclosures.

Correspondence to Dr. Ginat: dtg1@uchicago.edu

1. Ellchuk TN, Shah LM, Hewlett RH, Osborn AG. Suspicious neuroimaging pattern of thrombotic microangiopathy. AJNR Am J Neuroradiol 2011;32:734-738.

2. Reddy SC, Quah SH, Low HC, Jackson N. Prognostic significance of retinopathy at presentation in adult acute leukemia. Ann Hematol 1998;76:15-18.

\section{Pî Neurology.org Offers Important Information to Patients and Their Families}

The Neurology ${ }^{\circledR}$ Patient Page provides:

- A critical review of ground-breaking discoveries in neurologic research that are written especially for patients and their families

- Up-to-date patient information about many neurologic diseases

- Links to additional information resources for neurologic patients

All Neurology Patient Page articles can be easily downloaded and printed, and may be reproduced to distribute for educational purposes. Click on the 'Patients' link on the home page (Neurology.org) for a complete index of Patient Pages.

\section{WriteClick ${ }^{\circledR}$ rapid online correspondence}

The editors encourage comments about recent articles through WriteClick:

Go to Neurology.org and click on the "WriteClick" tab at the top of the page. Responses will be posted within 72 hours of submission.

Before using WriteClick, remember the following:

- WriteClick is restricted to comments about studies published in Neurology within the last eight weeks

- Read previously posted comments; redundant comments will not be posted

- Your submission must be 200 words or less and have a maximum of five references; reference one must be the article on which you are commenting

- You can include a maximum of five authors (including yourself) 


\section{Neurology}

\section{Retinal and intracranial hemorrhage in acute leukemic disseminated intravascular coagulation}

Daniel Thomas Ginat and Gregory A. Christoforidis

Neurology 2015;85;107-108

DOI 10.1212/WNL.0000000000001723

\section{This information is current as of July 6, 2015}

\section{Updated Information \& Services}

\section{References}

Subspecialty Collections

\section{Permissions \& Licensing}

Reprints including high resolution figures, can be found at: http://n.neurology.org/content/85/1/107.full

This article cites 2 articles, 1 of which you can access for free at: http://n.neurology.org/content/85/1/107.full\#ref-list-1

This article, along with others on similar topics, appears in the following collection(s):

\section{All Oncology}

http://n.neurology.org/cgi/collection/all_oncology

CT

http://n.neurology.org/cgi/collection/ct

Intracerebral hemorrhage

http://n.neurology.org/cgi/collection/intracerebral_hemorrhage

\section{MRI}

http://n.neurology.org/cgi/collection/mri

\section{Retina}

http://n.neurology.org/cgi/collection/retina

Information about reproducing this article in parts (figures,tables) or in its entirety can be found online at:

http://www.neurology.org/about/about_the_journal\#permissions

Information about ordering reprints can be found online: http://n.neurology.org/subscribers/advertise

Neurology ${ }^{\circledR}$ is the official journal of the American Academy of Neurology. Published continuously since 1951, it is now a weekly with 48 issues per year. Copyright (C 2015 American Academy of Neurology. All rights reserved. Print ISSN: 0028-3878. Online ISSN: 1526-632X.

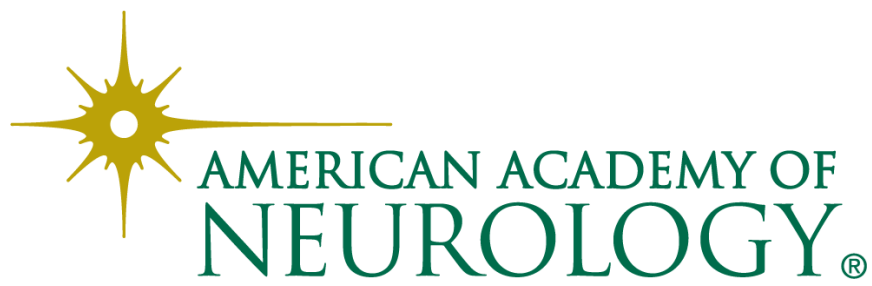

